This item was submitted to Loughborough's Research Repository by the author.

Items in Figshare are protected by copyright, with all rights reserved, unless otherwise indicated.

\title{
Student work on trends in infant and child growth - An editorial
}

PLEASE CITE THE PUBLISHED VERSION

https://doi.org/10.1127/anthranz/2019/1052

PUBLISHER

Schweizerbart Science Publishers

VERSION

VoR (Version of Record)

\section{PUBLISHER STATEMENT}

This is an Open Access Article. It is published by Schweizerbart Science Publishers under the Creative Commons Attribution-NonCommercial 4.0 International Licence (CC BY-NC). Full details of this licence are available at: https://creativecommons.org/licenses/by-nc/4.0/

\section{LICENCE}

CC BY-NC 4.0

\section{REPOSITORY RECORD}

Hermanussen, M, C Scheffler, D Groth, and Barry Bogin. 2019. "Student Work on Trends in Infant and Child Growth - an Editorial". Loughborough University. https://hdl.handle.net/2134/13237982.v1. 


\title{
Student work on trends in infant and child growth - an editorial
}

\section{Michael Hermanussen ${ }^{1, *}$, Christiane Scheffler ${ }^{2}$, Detlef Groth ${ }^{3}$, and Barry Bogin ${ }^{4}$}

\author{
1 Aschauhof 3, 24340 Eckernförde - Altenhof, Germany \\ 2 University of Potsdam, Institute of Biochemistry and Biology, 14469 Potsdam, Germany \\ 3 University of Potsdam, Institute of Biochemistry and Biology, Bioinformatics Group, 14476 Potsdam-Golm, Germany \\ 4 Centre for Global Health \& Human Development, School of Sport, Exercise \& Health Sciences, Loughborough University, \\ Leicestershire LE11 3TU, UK \\ * Corresponding author: michael.hermanussen@gmail.com
}

\begin{abstract}
Keywords: nutrition; impact on growth; geographic neighborhood; mortality bias; limb disproportions; physical activity; socioeconomic status; parental age; statistical tools
\end{abstract}

Students are supposed to read and to learn. But students are also supposed to question what they read. To do so they need to meet, to exchange ideas, and they need international platforms for discussions. Pursuing the goals of our previous International Student Summer School (Hermanussen et al. 2018), 12 Students from six countries met in Potsdam and nearby rural Gülpe (Ecological station of Potsdam University, Germany) for a one week retreat. All of them had collected data that referred to infant and childhood growth and contributed this material for focusing on new ideas and interpretations. Most though not all of these students finally succeeded in producing high quality publishable manuscripts of their work. Again, great interest occurred in the phenomenon of popular beliefs in nutrition and their impact on growth. We discussed how such beliefs tend to resist scientific evidence, and debated their consequences on infant feeding practices. Francis Friebel (Friebel et al. 2019) studied to what extent popular ideas and beliefs depend on culture and age and how they are related to child biology.

Another aspect of interest was historic material. Lidia Lebedeva (Lebedeva et al. 2019) had screened historic sources. Much of this material has quite completely disappeared from public attention. She re-analyzed mid- $19^{\text {th }}$ century body height of conscripts from the central provinces of the Russian empire. In those days, people's mobility was limited and serfdom an important political topic. Lebedeva showed to what extent physical mobility and geographic neighborhood influenced body height.

Laure Spake (Spake \& Cardoso 2019) focused on mortality bias in growth which is an important challenge and issue to the analysis and understanding of past populations. She showed that mortality bias in growth may exist, but it may not be large enough to impact interpretations of past population growth patterns. Anne Reimann (Reimann et al. 2019) addressed one of the biggest pharmaceutical scandals in post-war German history, the "Contergan scandal" of the late 1950s and early 1960s. Contergan (Thalidomide) when taken during early pregnancy can cause severe developmental disruption. World-wide more than 10,000 cases of infants with phocomelia due to thalidomide were reported. Reimann for the first time generated reference centiles for limb measurements that facilitate estimating the magnitude of limb disproportions and serves for improving the assessment of pension rights. Olga Parfenteva (Parfenteva et al. 2019) analyzed the association between sport specialization and the rs9939609 SNP in the FTO gene in cohorts of professional and amateur young athletes, and highlighted the importance of physical activity and sports on body composition. Paulina Pruszkowska-Przybylska (Pruszkowska-Przybylska et al. 2019) analyzed data on body composition and linked this material to socioeconomic status and parental age, as well as birth parameters and breastfeeding.

One of the main topics of this Summer School was the application, the dissemination and the utilization of statistical tools. Statistics is a difficult issue for students, but nevertheless, a linchpin of their current and later work. Rebekka Mumm (Mumm \& Scheffler 2019) used linear mixed effect models and structure equation modeling to analyze the influence of nutrition on height in data from the study "Young Lives" performed in Ethiopia, India, Peru, and Vietnam. They found randomly significant and non-significant effects with no evidence for a nutritional influence on height in children and adolescents in all countries. Amelie Fritz (Fritz et al. 2019) further developed Monte Carlo based approaches 
to the understanding of human growth. Based on the map of real street connections in Switzerland, and randomly generated networks, she modeled migration within spatial networks, and showed the influence of the network structure on the strength of secular height trends. Stimulated by these findings and many vivid discussions particularly regarding the interpretation of associations between parameters, and the inherent problems of detecting causality, Detlef Groth, Christiane Scheffler and Michael Hermanussen (Groth et al. 2019) inaugurated a new method for analyzing multiple linear correlations. The new technique helps translating multiple correlations into network graphs, and under particular circumstances, even allows for unveiling causal associations.

The manuscripts presented in this issue, result from original data, provided by students, and discussed in the light of their different sensitivity for scientific questions, and their heterogeneous personal and educational background. The Summer School helps students to carefully read, and learn to question prevalent concepts of knowledge. We hope that this concept is able to establish new and permanent international contacts, and may result in future cooperation and friendship between the participants.

Acknowledgments: We are grateful to Dr. Nägele, Schweizerbart Science Publishers, to have given the opportunity for young scientists to submit their research to this open-access platform. The Summer School was financially supported by the Auxological Society, and the German Gesellschaft für Anthropologie (GfA).

\section{References}

Friebel, F., Hermanussen, M., \& Scheffler, C. (2019). Popular ideas and convictions about factors influencing the growth as well as the adult height of children: A German-French comparison. Anthropologischer Anzeiger, 76. https://doi.org/10.1127/ anthranz/2019/0972 PMID:30994700

Fritz, A., Makeyeva, A., Staub, K., \& Groth, D. (2019). Influence of network properties on a migration induced secular height trend by Monte Carlo simulation. Anthropologischer Anzeiger, 76 . https://doi.org/10.1127/anthranz/2019/1032

Groth, D., Scheffler, C., \& Hermanussen, M. (2019). Body height in stunted Indonesian children depends directly on parental education and not via a nutrition mediated pathway - Evidence from tracing association chains by St. Nicolas House Analysis. Anthropologischer Anzeiger, 76. https://doi.org/10.1127/ anthranz/2019/1027 PMID:30990515

Hermanussen, M., Scheffler, C., Groth, D., \& Bogin, B. (2018). Editorial Perceiving stunting - Student research and the "Lieschen Müller effect" in nutrition science. Anthropologischer Anzeiger, 74(5), 355-358. https://doi.org/10.1127/anthranz/ 2018/0858 PMID:29461565

Lebedeva, L., Groth, D., Hermanussen, M., Scheffler, C., \& Godina, E. (2019). The network effects on conscripts' height in the central provinces of Russian empire in the middle of XIX century at the beginning of XX century. Anthropologischer Anzeiger, 76. https://doi.org/10.1127/anthranz/2019/0984 PMID:30994699

Mumm, R., \& Scheffler, C. (2019). Lack of evidence of nutritional influence on height in four low and middle-income countries. Anthropologischer Anzeiger, 76. https://doi.org/10.1127/ anthranz/2019/0988 PMID:31157817

Parfenteva, O. I., Groth, D., Scheffler, C., \& Zaharova, M. F. (2019). Influence of the A/T polymorphism of the FTO gene and sport specializations on the body composition of young Russian athletes. Anthropologischer Anzeiger, 76. https://doi.org/10.1127/ anthranz/2019/0943 PMID:30865763

Pruszkowska-Przybylska, P., Sitek, A., Rosset, I., Żądzińska, E., Sobalska-Kwapis, M., Słomka, M., \& Strapagiel, D. (2019). The association between socioeconomic status, duration of breastfeeding, parental age and birth parameters with BMI, body fat and muscle mass among prepubertal children in Poland. Anthropologischer Anzeiger, 76. https://doi.org/10.1127/ anthranz/2019/0955 PMID:30816407

Reimann, A., Beyer, R., Mumm, R., \& Scheffler, C. (2019). Reference tables with centiles of limb to body height ratios of healthy human adults for assessing potential thalidomide embryopathy. Anthropologischer Anzeiger, 76. https://doi.org/10.1127/ anthranz/2019/0981 PMID:30869735

Spake, L., \& Cardoso, H. F. V. (2019). Indirect evidence for biological mortality bias in growth from two temporo-spatially distant samples of children. Anthropologischer Anzeiger, 76. https://doi.org/10.1127/anthranz/2019/0957 PMID:30816412 